\title{
Creatinine clearance with cimetidine in the elderly: response to Dr. Chia-Ter Chao
}

\author{
C. G. Musso $\cdot$ J. Reynaldi $\cdot$ B. Martinez $\cdot$ \\ A. Pierángelo $\cdot$ M. Vilas $\cdot$ L. Algranati
}

Received: 26 May 2011/Accepted: 1 June 2011/Published online: 28 June 2011

(C) Springer Science+Business Media, B.V. 2011

Editor,

We thank Dr. Chia-Ter Chao for his comments about our paper. In responding, we will take the opportunity to correct a mistake. Unfortunately, in the paper, we reported the wrong dose of cimetidine: Instead of $800 \mathrm{mg}$ OD (once per day), it should have been written $800 \mathrm{mg}$ BID (twice a day), a dose most recommended in the literature for achieving a complete creatinine secretion inhibition (we referenced these articles in our original paper). We thank Dr. Chao for pointing out this error and giving us the opportunity to correct it [1-3]. Regarding Dr. Chao's comment on the accuracy of the method used for evaluating the renal reserve, we would like to emphasize that to evaluate this physiological variable we obtained the DELTA value between a peak GFR value and a basal one; thus, obtained DELTA value will be an accurate representation of the magnitude of GFR increase, independently of the accuracy of the applied method for measuring it. Regarding Dr. Chao's concern about the accuracy of urine volume measurement, we would like to clarify

C. G. Musso $(\bowtie) \cdot$ J. Reynaldi · A. Pierángelo .

M. Vilas · L. Algranati

Nephrology Division, Hospital Italiano de Buenos Aires,

Buenos Aires, Argentina

e-mail: carlos.musso@hospitalitaliano.org.ar

B. Martinez

Internal Medicine Division, Hospital Italiano de Buenos

Aires, Buenos Aires, Argentina that all the volunteers had a normal bladder voiding (presence of urine retention was one of the exclusion criteria evaluated before the study), and additionally, their urine residual volume was checked by bladder ultrasound after each micturition (this is mandatory when a timed clearance is evaluated). We agree with Dr. Chao that more research is needed in order to know how the aged kidney handles not only creatinine but also cimetidine.

\section{References}

1. Musso CG, Reynaldi J, Martinez B, Pierángelo A, Vilas M, Algranati L (2011) Renal reserve in the oldest old. Int Urol Nephrol 43(1):253-256

2. Musso CG, Michelángelo H, Vilas M, Reynaldi J, Martinez B, Algranati L, Macías Núñez JF (2009) Creatinine reabsorption by the aged kidney. Int Urol Nephrol 41(3):727-731

3. Musso CG, Michelángelo H, Vilas M, Martinez B, Bonetto A, Jauregui R, Algranati L (2010) Renal creatinine handling in very old patients with chronic renal disease. Int Urol Nephrol. doi:10.1007/s11255-010-9886-5 